

58 


\title{
PARKS FOR THE PEOPLE.
}

\section{PROCEEDINGS}

OF A

\section{PUBLIC MEETING}

HELD AT

\section{FANEUIL HALL,}

\author{
JUNE $7,1876$.
}

BOSTON :

FRANKLLN PRESS: RAND, AVERY, \& CO.

1876. 
60 


\section{CONTENTS.}

\begin{tabular}{|c|c|c|c|c|c|c|c|c|c|}
\hline ORGANIZ & $\mathrm{T}$ & ion of Meeting . & - & - & & & & & \\
\hline SpeEch & & Mr. Joseph S. Ropes & - & - & 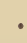 & ${ }^{\circ}$ & ${ }^{\circ}$ & & \\
\hline " & "6 & Mr. George B. Chase & • & . & & & & & \\
\hline “ & “6 & Mr. Richard H. Daxa, J & Jux. & . & 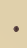 & , & • & & \\
\hline “ & 6 & Dr. Oliver Wexdell Ho & OLMES & & & & & & \\
\hline 6: & "6 & Rev. Rollin H. Neale, I & D.D. & . & & & 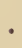 & & \\
\hline “ & “ & Rev. J. P. Bodfish . & - & - & & • & & & \\
\hline “ & " & Col. Charles W. Wilde & & - & & & & & \\
\hline " & "6 & Mr. Joseph F. Paul. & • & . & & & & & \\
\hline " & “ & Hon. P. A. Colurss . & . & - & & 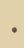 & $\bullet$ & & \\
\hline ETTER & & Dr. Enward H. Clarke & - & • & & 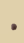 & & & \\
\hline MMIT & & OF ONe HuxdRed & . & $\cdot$ & & • & & & \\
\hline
\end{tabular}


62 


\section{FANEUIL HALL IEETING}

\section{Is \\ FAVOR OF PUBLIC PARKS.}

Pursonat to a call published in all the daily papers, and signed by a large number of prominent citizens and tax-payers of Boston, a public meeting was convened in Faneuil Hall on the evening of Wednesday, the 7th of June, 1876, to take action on the recommendations contained in the Report of the Park Commissioners. The hall was crowded by an intelligent and enthusiastic audience; and the proceedings, as reported verbatim in the columns of the "Boston Morning Journal," were as follows :-

The meeting was called to order at eight o'clock by Mr. JOHN W. CANDLER, who said, -

Gestlemen, - As Chairman of the Committee of Arrangements, I have been requested to call this meeting to order. It is usually the case, that, when a mass meeting of citizens is to be held, a great deal of labor has to be performed in preparing for and organizing the meeting. But I am glad to say, that, on this occasion, the important advantage of having a public almost entirely in our favor was enjoyed by the Committee. We found a strong and intelligent and deep-seated sentiment almost unanimous throughout the community, in favor of having the City Government take prompt and favorable action upon the report of the Park Commissioners. [Applause.] We found the community earnest and enthusiastic in the desire that a system of parks should be projected for the city of Boston, to insure the health, and to make certain and positive the prosperity, of our citizens in the future. The Committee had only to 
present the call or address through the press, which some of you have read, to find hundreds ready to indorse it; and the authorities had only to open wide the doors of Faneuil Hall to have the people throng here, as they have to-night, to manifest the sentiment which they feel so generally.

Gentlemen, we have with us to-night men of science, philanthropists, the representatives of the learned professions. We have the capitalist; we have the merchant; we have the mechanic ; and we have the daily laborer, who toils from the rising to the setting sun, - we have them all here, to give out a voice to-night, expressing the opinions of the people, which can neither be misrepresented nor misunderstood. [Applause.]

It is not my duty, gentlemen, to make a speech. You have here this evening to address you, the representatives of every class, the best that can be afforded in any city, the leading men of the city of Boston in the different professions. It is only necessary, in the discharge of my duty, that I should read to you the names of the gentlemen whom you will be asked to elect as the officers of this meeting. They are as follows:-

\section{PRESIDENT.}

THe Hox. JOSEPH S. ROPES.

\section{TICE-PRESIDENTS.}

Charles Fraxcis Adays, Williay Ayort, Richard Frothisghay, Peter C. Brooks, Martix Brimaer, George C. Richardsox, Bexjamix F. Thomas, Edward S. Raxd, Hexry P. Kidder, Thomas J. Gargax, Ebex D. Jorday, C. A. Richards, Johy C. Crowley, Williay B. Bacoy, Aarox D. Williass, Charles F. Doxxelly, Wy. W. Clapp, Bexuamix Dease, Richard Olxey, William Athertoy, Thomas Gogis, William Exdicotr, jus., Albert Bowker, Daxiel J. Sweener, Patrick T. Jachsor, R. M. Pelsifer, Rolaxd Worthisgtos, Johy G. Blake, M.D. J. H. Chadwick, Lewis Colemax.

\section{SECRETARIES.}

HAJILTON A. HILL.

WILLIAM E. PERKINS.

The list of names was unanimously approved; and the announcement of the election of the gentlemen named therein was received with applause. 
Mr. CANDLER continued, I have the honor of introducing to you Joseph S. Ropes, Esq., a merchant of Boston, who has been called to fill a great many places of trust, and who has always been found able in the discharge of every duty, and faithful in every trust committed to him.

\section{SPEECH OF MR. JOSEPH S. ROPES.}

Fellow-Citizens, - I thank you for the honor you have done me in inviting me to preside on this auspicious occasion. You have come together to-night, not to quarrel with one another's politics, not to abuse one another's rival candidates, but to hold a friendly consultation upon one of the most important and interesting and agreeable subjects which can engage your attention, - the subject of public parks for the city of Boston. [Applause.]

Gentlemen, I was born in Boston; and I well remember the time when our cows were pastured on Boston Common, when the Back Bay was not a myth, but a reality, and when at least a portion of the summit of Beacon Hill was covered with green fields, on which were seen sometimes "raree shows" and travelling menageries. Since that time, our city has grown and swelled, and stretched itself north and south, and east and west, striding over one arm of the sea, filling up another, swallowing the neighboring towns one by one, taking two mouthfuls for Roxbury, and one for Dorchester, and one for Charlestown and Brighton together, until it has expanded its population sevenfold, and its area almost seventy times seven, within fifty years. Yet there stands Boston Common just where and just what it was - no larger, and thank heaven! as yet no smaller [loud applause] — than it was fifty years ago.

Where are the breathing-places for this enlarged metropolis? Where are the places of common resort for quiet and healthful enjoyment and peaceful recreation for this expanded population? Where are the noble parks and the wide-spreading groves? Where are the places fit for public entertainment, which we find in every other large city in the civilized world? - such as we 
see in London and Paris and Berlin and Vienna and Florence and Rome and Naples - yes, even for the few brief months of summer, in the northern capitals of Stockholm and St. Petersburg? And echo answers, "Where?" [Laughter and applause.]

\section{"Gone like a vision!"}

My friends, I need not tell you that this matter has excited the interest of our philanthropic and public-spirited citizens, and especially of the medical faculty, to whom it is, in its sanitary aspect, a matter of most important practical interest. And, through their representations to the city government and to the state legislature, a bill was brought before the legislature, which I had the honor myself to report in the House of Representatives a little more than a year ago, and which was passed by large majorities in both houses, authorizing the city of Boston to purchase and to take lands within its own limits for laying out public parks, and to co-operate with adjacent towns in laying out conterminous parks for the common benefit and advantage of citizens on both sides of the line.

This measure was opposed (as all such measures are opposed) on the ground that "it would lead to jobbery and extravagance." And the answer was ready at hand, that all public enterprises are liable "to lead to jobbery and extravagance," but that the abuse of a good thing is no argument against its valid use [applause]; that it is for the citizens themselves, and for the government of the city of Boston, to see that their trust is rightly and honestly carried out.

Again : it was argued that the people of Boston possess already, in their beautiful suburbs, all that is required in pure air and beautiful scenery. And this, again, is most true as regards those who live in those suburbs, and those whose wealth enables them to pass to and fro in their carriages, and regale their senses with the luxury of what they there find. But what application has this, my friends, to the working-man, to the masses of our population, whose sole idea of the suburbs consists of an hour's rattling drive in a crowded street-car, and an hour's seat by the side of a dusty thoroughfare? 
Again : it was argued that the city of Boston could not afford this expensive luxury of parks. And to this again it was easy to reply, that so long as the city of Boston could afford prisons and jails, and any number of millions spent for liquor and for hurtful indulgences, and for the repression of vice and crime, it could afford to spend money for this peaceful and healthful and elevating enjoyment for the people.

In a word, gentlemen, this bill became a law; and, in pursuance of that law, a Commission was appointed by the city of Boston, the names of the gentlemen composing which Commission I need not repeat to you; for they are in all your hearts, as well as on all your lips. The Report of that Commission is now, and has been for weeks, in your hands ; and it is the object of this meeting to indorse that Report, and to stimulate and incite the government of the city of Boston to act in accordance with its suggestions. We cannot expect that all its details will be approved by every one; nor are we to suppose that all its details will be carried out in action by the government. But it is not too much to say that it is so well digested, so full and complete, and in every way so satisfactory to the city and the citizens, that we cannot do better than recommend it as a whole to the municipal authorities. [Applause.]

Now, my friends, it is not for me to do what will be so much better clone by those who succeed me on this platform, - to give you the reasons, and enforce the arguments, for your action at this time. But as a representative of the city of Boston, as an almost constant resident within it for nearly thirty years past, as in my humble sphere a representative of the merchants of Boston, as a taxpayer of Boston, and in every way identified with the best interests and all the highest and best aims of our city, I call upon you to-night to adopt and to indorse and to commend this admirable system to our city government. [Applause.] I have now the pleasure of introducing Mr. George B. Chase, who will present the resolutions. 


\section{SPEECH OF MR. GEORGE B. CHASE.}

Mr. President, - On behalf of the committee who have had in charge the arrangements for this meeting, I have the honor to offer for its acceptance several resolutions which have been prepared for it by a gentleman, than whom none is more versed in all that relates to the business questions and interests of the city of Boston, and who, during long and faithful service as secretary of the Board of Trade, became familiar with all subjects relating to the development and prosperity of the city. It is hardly necessary, Mr. Chairman, in such a connection, to mention the name of Mr. Hayiltox A. Hill. [Applause.]

Mr. Chase then read the resolutions as follows:-

Resolved, That this meeting would hereby emphatically re-affirm the opinion which has been expressed, at the polls and elsewhere, by the citizens and tax-payers of Boston, that the time has arrived when this city should be provided with a park or parks similar to those which have been projected by the other great cities of the United States, adapted to the wants of our large and steadily increasing population, and on a scale commensurate with the growing commercial importance and metropoli$\tan$ influence of the city.

Resolved, That the plan for a system of parks and parkways, prepared and recommended by the Park Commissioners, commends itself to this meeting as broad and comprehensive in its general features, fair to all sections of the city in its details, admirably suited to meet all the necessities of the case, and promising, when carried out, to make Boston one of the most healthful, attractive, and beautiful cities in the world.

Resolved, That the pressing need which exists for a radical improvement of the sewerage in some parts of the city, the present cheapness and abundance of labor, the diminished value of land, and the exceptionally farorable terms on which the city can now negotiate for money, render it of the first importance that there should be no delay on the part of the city government in the acceptance of the proposed plan, and in the adoption of decided and vigorous measures for carrying it into execution. 
Resolved, That this meeting would therefore respectfully and earnestly ask for immediate and favorable official action upon the Report of the Commissioners, and that the chairman and secretaries are hereby authorized and requested to communicate a copy of these resolutions, properly authenticated, to his Honor the Mayor, and to each branch of the City Council.

Resolved, That a committee of one hundred be appointed by the Chair, to represent this meeting before the city government, and to secure the desired action by it without loss of time.

The Chatryan. Gentlemen, you have heard the resolutions, which evidently meet with your unanimous approbation. You will now be addressed in behalf of these resolutions by one who needs no introduction from me, Mr. Richard H. DAXA, Jun. [Prolonged applause.]

\section{SPEECH OF MR. RICHARD H. DANA, JUN.}

Fellow-Citizexs, - I thank you from the bottom of my heart for this very kind welcome I have received at your hands to-night on coming upon the platform. I assure you, gentlemen, if I felt at liberty to waste the precious hours of this evening upon any thing relating to myself, I could say much more than I do to thank you for your great kindness.

But, gentlemen, we are met here on public business. You have heard what we are asked to do. We are asked to petition the city government, and send a committee of force to the city government (not as if the government were at all reluctant, but that they may know the feeling of the people of Boston), and ask the city government to go to work at once, and see that Boston has, as soon as possible, these necessities for her honor, her health, and her beauty. [Applause.]

In thinking of this subject, Mr. President and gentlemen, it occurred to me that it was a very singular fact, and not altogether to the credit of human nature, that great numbers of persons cannot live together without extreme inconvenience. Now, Robinson Crusoe, when he lived on the Island of Juan 
Fernandez alone, was not troubled with any question of public parks, or drainage, or health. Things took care of themselves. But when you get two or three or four hundred thousand Robinson Crusoes in a few square miles, you find the whole state of things is reversed, that you require all the patience, all the science, a large part of the money, and a large part of the industry, of the population, that you may live at all, and on any terms. The lower parts of our nature, the animal parts, tend to produce certain results which the intellectual parts are expected to meet and control. If they do not that, men become savages; if they do, they are enlightened.

Now, in this great and enlightened city of Boston, the pride of us all, the "Athens of America," as we all know we are [laughter], and, as our friend Dr. Howsres there has told us, the "Hub of the Universe" [laughter], it would hardly be respectful to say that one of the questions before us was, Which of those two roads we were going to take, - whether we were going to let the intellectual and moral parts have the upper hand, or whether we were going to sink beneath the material part. And yet, gentlemen, that is a good deal the question that is before us to-night.

Why, look at the progress which is inevitably made where you get great numbers of human beings together. You must have drainage, you must look to the health of the population, and then you must look to their recreation and their amusements (for they will have them); and, if they are not good and creditable and honorable, they will not cease to exist, but they will come before us in the most shameful and unwholesome form. We used to be told, gentlemen, that Boston had natural parks all about her, and she did not need any artificial parks. Well, now, I am not in favor of any artificial parks. All I ask is, that the beauty of the environs of Boston may be preserved. [Applause.]

We are on the defensive. We are defending the wholesomeness and the beauty of our beloved city against this encroachment of population. Why, the time was - Mr. Ropes will tell you when the time was - when the Back Bay was a beautiful sheet of water, filled at high tide, carrying the healthful air 
through the whole city. But then the necessity of population called for its filling up, and it is now piled in upon, and we have there now what Dr. ChARKE called "a natural cesspool."

We changed the Back Bay from a beautiful bay, where the wholesome tides of the ocean swept in, to a natural cesspool.

Well, now, look at the lanes and roads in the suburbs of Boston - beautiful. As you ride over them, there are trees hanging over them, and there are bushes on each side: you say it is charming. Well, go out there the next year. The selectmen if it is a town, the city government if it is a city, have changed all that. They have made a straight line right through it, and widened the streets sixty feet; cut down every tree, and made it one of the most disagreeable and painful spectacles that the eyes could rest upon. It is their duty so to do: it is a necessity. And so you go on destroying the beauties of the city, destroying its wholesomeness, destroying its charm; and now we have got to meet that tendency, and we have the power to meet it. We have the intellect, we have the money, we have the will, and we have the taste; and we would be incensed if any one should suggest that we do not. And yet we have allowed every city in the United States to get in advance of us. [A voice, "That's so."] Chicago has three thousand acres of parks; Philadelphia, five thousand; New York, one great park 'of about one thousand acres; and almost every city in Europe has better, more handsome and attractive accommodations than the city of Boston. I am ashamed to say it; but it is so. I trust, however, gentlemen, that, before I ever have the honor of addressing you again, we shall have taken the first step to remove this odium from the city of Boston. [Applause.]

Some six years ago, I think it was, the people got greatly in earnest that this park should be undertaken. They saw that the progress of the manufactories was fast destroying the beauties of Boston; that they were taking up the land in the suburbs apidly: and, when I said that your green lands were destroyed, with their beautiful curved lines, I forgot to mention that your beautiful sheets of water are in the same danger. Why, look at Fresh Pond, look at Jamaica Pond! They are beautiful objects to gaze upon : but when manufactories begin to surround 
them, when there are soap manufactories and tanneries, and I do not know what, draining into the pond, the result is, that the water is unwholesome, that the fish clie, the water cannot be drunk, and then physicians begin to tell their patients, "You had better move out of that neighborhood." Are you aware, gentlemen, that that is coming upon us, that we must meet it, and avert it?

Some years ago, the people of Boston were earnestly in favor of a park, or system of parks. The legislature, for some reason or other, required that the project should receive a vote of twothirds of the people. That was extraordinary and hard. But it did receive a vote of two-thirds of the people of Boston proper, and more than two-thirds; but from the accident of a newly added portion of the city, for some reason or other, taking a slant in a certain direction, they voted very largely against it, and it fell through. We must take warning from that; for land that would have made then a handsome park, which we could have had, we cannot have now at all. It would cost altogether too much to much to take dwelling-houses and factories and railroad beds, if we could, for a park.

Well, after six years of restlessness, at last we went before the legislature again; and we got an act passed, authorizing the appointing of commissioners with powers. That act passed, helped by our most able fellow-citizen, Mr. Ropes, chairman of this meeting; and it was submitted to the rotes of the people of Boston; and the park project was carried by the votes of this entire population, - Boston, East Boston, Charlestown, South Boston, Dorchester, Brighton, which make, all together, a very large and most decisive majority. And therefore, gentlemen, the question is not, Shall we have parks? you have decided that; but the question is, Whether, having determined to have them, we shall rest content with saying so? whether we will have our paper parks, as we have our paper money, with nothing to rest upon [laughter], or whether we shall have genuine parks, with life and trees, and have sheets of water? Now we are here to-night to say it is the latter that we want. [Applause.]

Fellow-citizens, that statute authorized the appointment by the Mayor, subject to approval, of three commissioners. Well, 
that was wise. It was not nine, seven, nor five; but it was three. Well, his Honor the Mayor, who has presided with so much dignity, wisdom, and integrity [applause] over the city of Boston for two years, - and we would be glad to get him for a third year, if his health would permit it [applause], - his Honor the Mayor appointed three gentlemen as commissioners, in whom this community have entire confidence. There are no politics among the Board of Commissioners; there is no jobbery in the Board of Commissioners ; and I will venture to predict, gentlemen, that, when they finish there task, there will be no investigation. [Great applause.]

I was amazed on looking over their charge. Why, I found an item of coach-hire for the whole period of their service, nine dollars. Why, it would not have been enough to take three common councilmen from Parker's or Young's. [Laughter.] But it is all they have charged; and how, on that sum, they succeeded in riding around Boston, I do not know. Their experience with persons who let carriages must have been much more favorable than mine has been. But not only have they done honorably, economically, and frugally, they have put into their work an amount of brain-labor, an amount of patient investigation and of good judgment, which no one can have an adequate opinion of who has not read their book; but, if he has not, I hope he will. And at least this I may be allowed to say, I do not think any citizen of Boston has the right to object to those parks, or to be silent or indifferent on the subject, unless he has read the Report of the Commission, and knows what is proposed, and has been done. [Applause.] They have consulted the best authorities. They have consulted Mr. Frederick Law Olustead, who laid out Central Park in New York, and he is the highest authority on the construction of parks in the country; and he has been all over this neighborhood, viewing the localities, and they have taken every thing into consideration; and, gentlemen, what is the result? They do not propose to us one great park of a thousand acres, at an almost unattainable distance; they do not propose a great park that nobody can get to, unless he gives a day to it, and a good deal of money : but they have adopted a system based upon the natural character- 
istics of the neighborhood of Boston. And what better could they do? At East Boston, they have given them a park upon the water-side, where they will always have the fresh breezes of the sea. At South Boston, they have given them a park upon the water-side, one directly opposite Fort Independence, and then another one, called the South Park, larger; and Chester Park, which you are all familiar with, is already extended, and nearly ready to be used as far as Beacon Street; and thence it is to go over to Cambridge, and be the quickest means of access to the University. That same avenue is to be extended easterly till it strikes the farthest of the South Boston parks, opposite Fort Independence ; and, when that is done, you will be able to drive or walk, according to your powers of walking, from the park opposite Fort Independence, into the city, and across it, to Harvard University.

Now that is a good deal; but they have taken another step. They propose to take the water-front of the Charles River basin; and there is nothing in Nature so beautiful, so well adapted to the needs of a city, as a park, or boulevard, or promenade, directly on a water-front, especially if that water is seawater, - if it is brought in and carried out by two daily tides. What more beautiful, what more wholesome, what more invigorating, during the hot season of the year, than to have an open boulevard, where you can sit, or walk, or ride,-a place for the fresh sea-water of the ocean brought in pure to you every day! Well, they mean to preserve that, and give us about two hundred feet for a driveway, a saddle-horse way (a saddlepad, I think they call it), and footpath, a place for flowers and trees, as it extends along the water-side, beginning by Leverett Street, and going out as far as Brighton. Then from there they mean to take this great Back Bay, which Dr. Clarke properly called a natural cesspool, and keep a large part of it under water, the ocean to be let in and let out at our option, so that it can be always kept pure; and yet such a quantity of it, that it will be a sort of inland sea, where we can have regattas, and where every gentleman may keep his boat, and every boy may keep his scull; and perhaps it is just as well a boy's skull should be there as anywhere else a large part of the time. [Laughter.] 
Then, gentlemen, they are going to take Jamaica Pond, and have a park or driveway around the pond; then the Chestnut Hill Reservoir, that has a parkway one hundred feet in width, where you can drive or walk at your pleasure. In West Roxbury they are to have a mountain-park, which will be the largest (about five hundred acres); and it is well called a providence, because it is high, it is rocky, it has a thoroughly sylvan look, like a forest. You would feel as if you were fifty miles from Boston, if you were where you could not see the city. At the same time, it is beautiful for a park. There are very few houses there; and it is difficult to make it salable for residences. But they have selected this spot; and they are going to give us the best park of the city, and then have all these parks connected by parkways, thus making them so convenient of access, that every poor man in Boston can take his child by his hand, and for five cents a head can be carried out to any one of those parks by the railroads. [Applause.]

And, when he gets there, he can show this poor boy or girl, who has passed all the winter, and all the opening spring, in an alleyway, - he can show them, by a wholesome ascent of two hundred feet only, slow, gradual, one of the noblest prospects in the world, - the ocean pouring up into these great bays, and floating the great ships that come and go, the Bunker Hill Monument and the Navy Yard, the University, and the great series of cities that surround us. And, more than that, he can show him or her IVachuset Mountain, and even the top of Mount Monadnock in New Hampshire.

Now I ask you, fellow-citizens, if it is not worth while for the city of Boston to improve these opportunities. We have been most fortunate in our Commissioners, - in their wisdom, in their frugality, in their intelligence, and their public spirit; and I hope, gentlemen, you will study their Report. It is easy reading, pleasant reading; and if, when you get home, you find your boy or girl engaged over some novel, especially if it is a yellow covered one, take it right out of his or her hand, and ask them to read that Report.

You may think it absurd; but, ten to one, it will interest the children more than the novel would. It will certainly give 
them more valuable instruction; and I venture to say it will interest them more. I felt quite carried away by it. It seemed to me it must be a fancy; but, when I turned to their accounts (and they are all mercantile men), I was amazed to see at what small cost it could all be done. And, gentlemen, I want to detain you a moment longer on statistics, and show that it has increased the value of property in every city that has had a park, by bringing houses all about the parks, and by detaining as inhabitants of the city, to be taxed in the city, those men who skulk in small towns to throw the burden of the expense of their own city on those who stay behind. [Applause.] All we want to do to-night is to say to the city government that we are in earnest about this matter, and that we want the work done now. [Applause.]

I tell you, gentlemen, it is very doubtful, if this fails, whether you will have another Board of Commissioners to compare with the present. I tell you it is doubtful, whether there will be a state of things in Boston which will be any thing like as favorable as the state of things we are in now. But I can tell you one thing that is certain; and that is, if you postpone it, you cannot have the parks that they propose. The growth of population will be crowding over it; speculators will buy it; the ponds will become injured; and the expense will be so great, that you will shudder at the thought of it. And, more than that, the parks that you ask for in another ten years will be four or five miles from the centre of population now, and I confess that one great argument with me for instant action is, that I want the parks to be as accessible as possible to all those persons especially who do not own their private carriages, and cannot give a day to it. [Applause.]

And last of all, Mr. President and gentlemen, it should be done for economical reasons, as has been stated very well by the address and in the resolutions, because there never was a time, and I hope there never will be a time again, when the land was so cheap as it is now ; and, when we take this land for parks, we take it at its present price. There has not been a time for many years, and I hope there never will be a time again, when the price of labor is as low as it is now [applause]; and that 
labor we would employ at once, and the laborers are begging for employment. Why, there is not one of you who has not often and often, within the last two years, perhaps it is not extravagant to say, felt his heart bleed when he has been stopped in the way by evidently honest men, who would say, "We can't find any thing to do. We have looked everywhere; and there is no work for us." [A voice, "That's so."] Yes, that is so. Now, some philanthropists, and some political economists, have told us that the government ought always to find employment for everybody ; it is the duty of the city to see that everybody has work: but, though I do not advocate any such doctrine as that, I advocate this doctrine, - that whenever the community has any thing it ought to do, and which will employ liaborers (and this is a hard time on the laborers), then is the time that they ought to do it. [Applause.] So that it is not only good economy, but it is humanity, that dictates an instant advance upon this work. To save the land that we can get now in a low market, and to employ laborers who are paid low wages, but are glad to get even that, and to prevent the entire failure of this scheme so carefully and beneficially made, we shall ask the city government to work at once.

Now, there are others much more able to speak of the finances of the city government than I am; but we always do find, that, when a thing ought to be done, there is a way of doing it; and we sometimes find, that, when things ought not to be done, there is a way of doing them. I wish to say one word more, before I take my seat, on the report and scheme of these Park Commissioners; and that is its entire equitableness in its attention to localities. It has left no part of the city that is not benefited. Charlestown cannot have a park, because it is built over, and there is no room for one. If there was room, they would have one. They must annex; and then they can have a park. [Laughter.] East Boston has a park; South Boston has a park; then comes the great West Roxbury Park; then comes the Bussey Farm, which I omitted to mention; and then comes Jamaica Pond and Chestnut 'Hill Reservoir Park, and the park roads connecting them all, and uniting them; and then the water-front 
on all that part of the city of Boston where the water-fronts are not needed for commerce.

I say, therefore, this plan is equitably divided among the citizens according to their residence; and it is accessible to all, and the plan is economical, and the time is auspicious. Therefore I hope that you will with unanimity adopt the resolutions, and call upon the city government to proceed at once. [Applause.]

The Presidext. Allusion has been made to the "Hub of the Universe;" and you will all understand, that, when any thing is the matter with that Hub, the diagnosis must be made not only by an able physician, but by an able spokesman. [Laughter and applause.] I have great pleasure in introducing to you one who combines both, and a hundred other qualities, Dr. Oliver Wexdell Holises. [Applause.]

\section{SPEECH OF DR. OLIVER WENDELL HOLMES.}

You will not ask for rhetoric or eloquence in the few remarks upon a vital subject to be offered you by a member of the silent profession. What could be so eloquent as the hollow roice which announces the Boston annual death-rate as being 26.18 against 23. $\overline{\text {, }}$ that of the great paved nation of London; against 19.3, that of Philadelphia ; and approaching that of our two unhealthiest cities, New York and New Orleans? This high death-rate has been shown to be largely due to the excessive mortality among infants and children under five years of age. The most fatal of the diseases which assail them is that destruction which wasteth at noonday, to which our American practitioners give the name of cholera-infantum. And this disease prevails chiefly, almost entirely, from June to October, the season when all out-of-door influences are most tempting and most needed. The weekly record of August and September is that of a pestilence. The destroying angel carries off the firstborn, and, oftener still, the last-born, out of almost every household in certain districts, as in the heaviest curse laid on Egypt. Thousands have fled the city, as they deserted London in the 
season of the plague; but thousands are left to follow in the funeral procession of those who were the hope of their households.

A considerable part of this mortality, it may be feared, is unavoidable. Our climatic influences are permanent factors, and must always count in the bills of mortality. But there are certain agencies which we can, to a great extent, control. We can and do submit the dwellings of our citizens to inspection and sanitary regulation; we can and shall provide our city with proper drainage ; we can and do inspect the food in our market, and condemn it if unfit for use; we can and must secure for our citizens the influences of unroofed and unwalled Nature, air, light, space for exercise and recreation, the natural birthright of mankind.

Of the uses of these larger breathing-spaces, which we call parks, - for the relief of the imprisoned dwellers in crowded streets, for the recreation of poor and rich alike, for the health of mind and body which they offer to all, - it seems almost needless to speak from the medical point of view; for all know what cities would be without open areas, where children can play in the shade, and old people warm themselves in the sun. I wish to call your attention to a single point intimately connected with the alarming fact of the excessive death-rate of which I have spoken. That point is the influence of the air they breathe on the health of children, with the bearing of this on the question before us.

If a child is found to have been starved to death in a cellar or an attic, a cry of horror is raised over it. If two or three wandering boys, as it happened the other day at Lowell, come upon some noxious roots, and, in obedience to their omnivorous instinct, devour them, and pay the forfeit, the whole country hears of it. If a family or two get hold of some ill-conditioned meat, and suffer for it, the groans of their colics are echoed all over the land. If a milkman misrepresents his honest cows by falsifying their product, the chemist detects him, and the press puts him in the pillory. If the Cochituate or Mystic water is too much like an obsolete chowder, up go all noses, and out come all manner of newspaper paragraphs from "Senex," 
"Tax-payer," and the rest. But air-poisoning kills a hundred where food-poisoning kills one. Let me relate a circumstance which happened in Ireland, to which circumstance, in all probability, I owe the pleasure of being listened to at this moment by some among our hard-working, adopted citizens who are before me.

When I say to you, meaning to speak the words of sober truth, that a single physician, by a single and simple measure, saved more lives than were lost at Waterloo by the British army and all its allies, leaving out the Prussians, you will suspect me of exaggeration, not very uncommon in public speakers. I will therefore intrench myself behind certain details which I have often before cited, but not in the presence of a gathering of this kind.

Dr. Robert Collixs was Master, as it is called, of the great Dublin Lying-in Hospital, where the annual rate of births was between two and three thousand, from the year 1826 to 1833. A work of his, containing the results of his practice during his seven years of service, was published in Boston in 1841, by order of the Massachusetts Medical Society, for the use of its members. I consider him vouched for as authority, therefore, by men in whom you can put confidence. Dr. CoLLINS makes the following statement:-

When his predecessor, Dr. JosepH Clarke, was in office, in the year 1784 , he found that seventeen children in the hundred, nearly one in six, died within the first fortnight after birth, nineteen-twentieths of these of one particular disease peculiar to very early infancy. Looking for the cause of this frightful mortality, he thought he found it in a foul and vitiated state of the air of the hospital. So he had some openings of considerable size made in the ceiling of each ward, and three holes, of an inch in diameter, through each window at top : the doors, too, were perforated with numerous holes. In this way, a free circulation was secured, and so arranged, that the nurses could not control it; for some of the old-fashioned nurses would not have opened a window in the Black Hole at Calcutta, for fear the inmates should catch a cold.

What was the result of this simple proceeding? Why, the 
mortality fell, from seventeen in a hundred, down to between five and six; and Dr. Collins gives us the result up to his time in these words, "Thus, by his valuable suggestions, 16,371 lives have been saved, as, had the mortality of infants continued one in six to this day (1833), the number of children dying of the 131,227 (which is the total number born in the hospital) would be 21,871 , as the hospital registry now shows." In the battle of Waterloo, the British and their allies lost $16,186 \mathrm{men}$; that is, 185 less than the great army of very light infantry saved from death by letting out the smoke of the battle of life, and letting in the sweet air of heaven, through the walls of the Dublin hospital.

So much for what air alone can do for children. Now, it is not the "nine-day fits" of that hospital in its unventilated condition which kills our poor children in the hot months, but that other disease of infancy, which to name is like sounding a funeral knell in the ears of many a parent. This one malady, more than any other, gives Boston its place on the black list of unhealthy towns. All parents having young children leave the city during the worst part of the sickly season, if they have the means of so doing. Our best streets look as DEFoE tells us London streets looked during the Great Plague. But thousands of families must remain; and we are bound to do what we can for them in their dearest interests, - the lives of their children.

With regard to cholera-infantum, - the deadly scourge of which I have spoken, - the testimony of experience shows that change of air, even temporary, often effects the cure of which the apothecary, who "pestles a poisoned poison behind his crimson lights," cannot bring about with his drugs, though the wisest of physicians had written the prescription. This point is so important, and bears so directly, not only on the necessity of park-spaces, but upon their distribution so as to bring them within reach of all the crowded and unhealthy districts as far as possible, that I shall borrow a few sentences, enforcing it, from writers recognized as authorities on the diseases of children.

"Even in cases in which a removal to a healthy and airy situation in the country is impracticable," says Dr. Conde of 
Philadelphia, long and well known by his writings, "much benefit may be derived from carrying the patient frequently into the open air in a carriage, or in the arms, or, when its residence is near a large river, sailing it daily in an open boat." And Dr. JoHx BELL of the same city says, "The restorative effects of fresh air in cholera-infantum are strikingly evinced in the relief procured by many hundreds of children every summer in Philadelphia, by their simply crossing and recrossing the River Delaware in steamboats once or twice a day. New life is restored to the little beings, who, on leaving their homes in the city, seemed almost exanimate, and in the last stage of incurable exhaustion." Dr. JAMEs StewART of New York, in his treatise on the diseases of children, and our own honored patriarch of the profession, the late Dr. James JAckson, in his letters to a young physician, speak in similar terms of the great advantage of change of place and of air. The "aquatic jaunts" recommended by Dr. STEWART, and spoken of as so efficacious by Dr. Bell, are among the advantages to be secured by the plan proposed by our Park Commissioners. I wish twenty tons of little children could be shipped every fine summer day for a good sail.

There is one particular region which I will mention as like to be specially benefited by the plan referred to, - a region which would get the advantages of the fresh air coming over the wide estuary of Charles River without the expense and trouble of taking boats. The narrow and crowded streets of the northern slope of Beacon Hill, and a wide region extending northward from it, are inhabited by the very class most exposed to cholerainfantum and diseases of that nature. Having lived for many years in Charles Street, where I am no longer an owner, I had occasion to learn the incomparable comfort and delight to be got in a hot summer's day, when the wind is from the southwest, by turning the corner of Charles and Cambridge Streets, and getting into the current of air cooled by passing over the water. Some of the poor mothers with sick children had found out where to bring them for relief; and I often thought, if there were an open green filling up that corner, with shade trees and seats, what a priceless sanatorium it would be to all that suffer- 
ing quarter of the city! The proposed green margin, beginning at Leverett Street, and extending along the river, will meet this very want; and this is only one locality of many which will thus turn its natural advantages to account.

I have preferred to insist on a single point rather than to expatiate on a larger number. But I trust that the eloquence of others will enforce and illustrate the innumerable advantages our city will derive from the only chain she would submit to, - a chain of pleasure-grounds all around her. The Bostonian has looked up at the gilded dome of the State House, and down at the reflection of his own features in the Frog Pond, long enough. Our city has always been a centre; and it must not act as if it considered itself a mere feeder. We must provide ourselves with the complete equipment, not of a village community, not of a thriving town, but of a true metropolis, large enough for a citizen of the world to live in without feeling himself provincialized, and not too large for one honest mayor like our own to handle. The marrow-bones of the past are pretty well cleared out, or will be before the Centennial year is over, and we must not be content to live on them for another century. The Old Elm got enough of it, - grew discontented, and started on its travels for wider quarters, but, unfortunately, stumbled and fell. Let us take the hint, and plant a thousand acres with young elms and all other trees of the forest, where the hillsides are not already clad in foliage ; so that the children of coming generations may bless our memory, not only for all the happiness they have had in their shadow, but for saving more lives to the country than were lost in any one of the battles which scarred and crippled their fathers. [Applause.]

The President. Gentlemen, you have been addressed by two of the learned professions. It follows, as a matter of course, that you will now be addressed by one from the third, the most important and most respected of all. I am happy to introduce to you the Rev. Dr. Neale, the oldest settled pastor of the city of Boston. [Applause.] 


\section{SPEECH OF THE REV. ROLLIN H. NEALE, D.D.}

I do not intend, my friends, to trespass much upon your time, and certainly shall not presume to give any new information on the subject which has been presented. Owing, probably, to my long residence here, it has been thought, I suppose, that my testimony, in these days of calling for witnesses, may be of some importance. Of the financial bearings of this proposed enterprise, of course I cannot judge. These are to be considered and acted upon by men on whom the public responsibility rests, who will, doubtless, act considerately and wisely; but the desirableness of the thing itself is unquestionable. I have had opportunity, with some gentlemen here present, of wandering of a summer's day through the beautiful and extensive parks of Europe and of this country, and know how welcome and refreshing they are to the weary traveller. "Boston Common," of course, we praise everywhere ; and when abroad, and thinking of dear home, say there is nothing like it.the world over.

It is a good feature in the character of Bostonians to love their own city. There is something delightful in its old buildings, and even its crooked streets. We forget political and even religious differences in view of ancient landmarks. We cling to the Old South, and would gladly have kept Brattle Square with its cannon-ball, whatever might have been thought of its theology. We cherish the memory of our fathers, and wish to keep among us, as far as possible, signs of the good old days. This is right and noble; but equally right, and quite as unselfish, is it to think of those who shall come after us. HorAcE BushNell was a scholar, and wrote many elaborate works on metaphysics and divinity; but the Bushnell Park of Hartford will probably be that for which coming generations will thank him most. Certainly it will keep his memory fragrant and green forever.

Our good city is justly famous for its hospitals and physicians, as well as its churches and clergymen. I hope the contemplated parks may not supersede the sanctuary and the sermon, though, as they say, there are "sermons in stones, and good in 
every thing." But certain it is, that a ramble through green fields at any time, and along sparkling streams, is better than a sick-bed, or the apothecary's drugs and doses.

We are all of us, I suppose, more or less subject to the blues, business-men, clergymen, and even politicians. In such cases, it is of no use to shut one's self up in the house, and brood over trouble. The best remedy is a walk, a good long stretch into the country, fresh air, a hearty laugh with some friend; or an exhilarating ride, Brother MURRAY would say, probably, behind a "perfect horse." And these are some of the blessings it is proposed to secure for us. The very season now here speaks impressively for this enterprise. The glories of a June day, how they make us yearn for rural scenes! Nature everywhere is beckoning. "The mountains and the hills break forth before us into singing, and all the trees of the field clap their hands."

The Presidest. We have listened with much satisfaction and enjoyment to the address of one of the clergymen of the city of Boston : but all denominations of the Christian Church are included in this call; and I am now happy to introduce to you the Rev. Mr. Bodfish, Rector of the Catholic Cathectral of the Holy Cross of the city of Boston. [Applause.]

\section{SPEECH OF THE REV. J. P. BODFISH.}

Mr. Presidext and Gentlemen, - I am happy to stand here, where so many of my ancestors have stood, and to address my fellow-citizens on such a measure of public importance. When this matter was first brought to my attention through the papers, when the plan proposed in all its grandeur first came before my mind, I was reminded of a saying of a musical friend of mine. He belonged to a band. He came from the fatherland; and his great specialty was to play on the trombone. After a while, it became rather remarkable, these solos on the trombone; and some of the college boys wanted to put him down a little: so they commenced by applauding. That seemed to have no effect. So one night they thought they would try 
another plan. He was flaying his best on the trombone; and one of the boys cried out, "Louder!" And so he began again on the trombone; and the boys said, "Louder!" And he tried again on the trombone; and the boys still cried, "Louder!" And they still kept on, "Louder !" until he almost burst every blood-vessel. And he put down his instrument in disgust and said, "It is very well to say, 'Louder!' but where is you going to get the vind?" [Laughter.]

Now when I thought of this system, and the immense expense it would be, I said to myself, Now, that is a grand system; it would be beautiful indeed: but where are you going to get the money? But then I took the Report of those able Commissioners, this pamphlet that is spoken of ; and I read it myself carefully to see if it was a practicable and feasible plan, and was surprised to see the ability with which the whole matter had been treated. So thorough had been their investigations, that they had demonstrated it was perfectly clear that this grand and beautiful system of parks could be built at this time, now, with a very slight taxation upon the whole business community; and, furthermore, that by the improvement of property in the neighborhood of the parks, and by the advantage to the city in general, the money expended would soon return to the taxpayers of the city; and so that objection is disposed of at once.

There seems to be no difficulty. There are so many solid men here in Boston, that a work of this kind surely can be carried out with greater ease than it has been in other cities; and we know in other cities they have reaped great pecuniary benefit from the establishment and building-up of their system of parks. But you would hardly expect a clergyman here to talk on the financial question: that is a little out of order. But the physicians have considered the medical point of view, the sanitary point of view, how necessary it is to the health of the city; and the financiers have demonstrated that it is easy in a financial point of view; and it would be natural for me to speak here to-night, perhaps, on the moral necessity of such a system of parks.

Now, when I think of the conditions under which a great 
many of our poor people live, I am not very much surprised that they are goaded into desperation to commit some fearful crime, because we know very well, where a person lives in the country, and has the blue sky over his head, and the running brooks gurgling through the meadows, and the green trees and villages, and every thing cheerful and pleasant about him, why, he is removed from a great many temptations that are common to a large city; and we know, that, in a moral point of view, the people of a town or of a country district are removed from a great many temptations and incentives to crime: therefore every one who wishes well for the religious welfare of the people would be glad to have these parks established as a real moral agent in the community and to the people of this city. And, as my respected friend has suggested, perhaps the people would rather go out in the park than to stop and hear our dull sermons. But I would run even that risk ; for the Lord's Day, you know, is a day of rest; and, after we pay our homage to our Creator, I think it would be pleasant even to Him to go and take your family, and take a stroll out into these pleasant parks that are proposed for your health. [Applause.]

And then there is another feature which pleases me very much. You know, in the olden time, the lords and nobles, and those who possessed the landed estates, they felt it their duty to provide for the welfare of the laboring classes, upon whom they depended really for their riches; for they tilled their lands, and brought them in their incomes and the returns from their estates: and so they watched over them with a kind of a paternal care; and, when they were sick, they provided for them hospitals, and they watched over them as a father would over his family. Now, we liye in a little somewhat different order of society; but still there remains the same common duty for the men of wealth, for the men who possess capital, to look out and provide for the wants and necessities of the poor, on whom they depend to a great extent; for capital cannot be independent of labor. [Applause.]

Now I see around me, I may say, the nobility of this city. They may not have long, sounding titles; but they have the wealth, they have the philanthropy; and their presence here 
to-night shows you that they have those same generous impulses toward the whole of this city's population. They have come here as a unit: they are willing to pay whatever is required to build this magnificent system of parks, that all the people of every class may enjoy its benefits. I say they are acting the part of the nobles of old; and they are taking care of the people of this city as though they had a certain paternal influence and responsibility toward them [applause], and it rejoices my heart. And in another point of view, we know that the safety of any community and society depends upon the contentment and happiness of all classes of its people.

If there is one class that is ground down, and unhappy, and living under unworthy conditions, they are, of course, immediately a dangerous element. I say that it is a matter of good policy, as a stroke of political economy, to provide for the wants of all classes of people in this way, that they may live contented and happy, and have every thing that is necessary for the health and recreation of their families. [Applause.]

I cannot, of course, at this late hour, delay you with arguments. You have had sufficient already. That, as I understand it, is not the chief object of our meeting here. The arguments are at present before the authorities in this excellent Report of the Commissioners.

We meet here to encourage them to go forward, to speak out in such a positive manner, that they can hesitate no longer. It is our duty to cheer them and encourage them in their work, and we hardly realize what an influence this meeting will have in encouraging them to the great and arduous work which they have undertaken to accomplish. Why, it reminds me of a little incident that happened in New York not long ago, when one of those great buildings was on fire, - those nine-story tenement-houses. When the great crowd gathered there in the night, and they were surging there, the police were trying to keep order, and the firemen were working, and the hot flames shot up toward the sky, and the black smoke rolled forth, and all was din and confusion; and, in the noise and tumult of that dark and threatening night, there was one voice heard. It was a mother's voice above the noise; and she cried, "Save my child! 
Will no one save my child?" And they would hush her; but still she cried, "Oh, save my child!" And there was one of the brave firemen, when he learned that a little child was in the fourth story of that building, who thought of his little ones at home; and he said he would risk his life, he would dare any thing, rather than that child should be lost. And they brought the great ladders, and they spliced them together, and they swung them up against the burning building ; and he commenced to ascend. And, when he was halfway up, he looked at the hot flames and the dense smoke rolling forth, and his heart trembled with fear : it seemed to be instant death. But some one in the crowd below, who knew the springs that govern the human heart, cried, "Cheer him!" " Cheer him !" And there went up from that great crowd the wild hurrah, and it cheered his heart like an electric thrill; and he rushed on, and disappeared in the smoke. All was suspense; they waited with breathless anxiety: and at last he returned with the child, and placed it in its mother's arms. [Tremendous applause.] So you see the power of a word of encouragement and cheer when any one has arduous work before him; and that is our duty here to-night, my fellow-citizens, - to speak out with one voice, and determined voice, and to cheer those who have undertaken this work, and to let them know that we are ready to support them, that now is the time, and that we are determined that this great work shall be accomplished. [Applause and cheers.]

The President. I shall now have the pleasure of introducing to the audience Col. Charles IV. Wrlder. [Applause.]

\section{SPEECH OF COL. CHARLES W. WILDER.}

This large gathering of our citizens in Faneuil Hall is for some purpose : it is significant that the people want something. I do not understand that it is in any sense to re-affirm their conviction that their best interests will be served by adding to our public property a park or parks. That question has been fully discussed and decided by the people themselves for themselves: 
they settled that by their, with remarkable unanimity, voting to accept the act of the legislature, giving power to the city government to purchase or take land for that purpose. All classes seem to agree upon the necessity. The entire medical faculty with one voice say we want it for sanitary reasons, and have joined in the general petitions. Our capitalists and merchants have spoken for themselves unmistakably by their petitions to the city government, bearing more than seven thousand names, and representing, I am informed, more than two hundred millions of taxable property. An able Commission, after a year of careful study, and diligent devotion to their duty, have made their report. 'The people have examined, discussed, criticised, and finally approved and accepted it, and now come here in Fineuil Hall to speak direct to City Hall for its adoption. Mr. President, our professional men, our merchants and capitalists, have spoken for themselves by their petitions and voices here tonight. It remains only for me to speak for the more numerous class of our fellow-citizens who pay but two dollars poll-tax. Yet they are as good citizens, have and feel as deep interest in the growth, prosperity, and progress of our city, as their more fortunate neighbors; and in the name and behalf of the mechanics, the laborers, the great mass of men that build our cities, and whose labor contributes so much to our growth and prosperity, and whose employment is the one thing more than any other needed to-day to inaugurate the beginning of our old-time prosperity, I appeal to our city government to complete the work so opportunely and well begun. It is immediate action we ask for.

There being no difference of opinion as to the necessity and utility of parks, and their ultimate payment for their full cost, the only open question is the time to begin. We say that time is now, - now, while thousands of unwillingly idle hands are waiting for work, and money is cheap; cheap, because labor is unemployed. We say to you, gentlemen of the city government, respectfully but earnestly, Act upon this matter now.

Don't wait till your summer vacation; don't wait till next month; don't let any personal matter intervene to prevent the performance of this public duty the people now ask at your 
hands. The present truly great debt of our city, the bulk of which has been created in improvements, made enormously more costly by the failure of city governments in past times to comprehend the wants of a growing metropolis, admonishes you to act now, and secure the advantages the present favorable combination of circumstances offers. IVe confer on you the power to spend our money for the public good; and we ask you to act now, because we clearly see that delay means largely increased cost for what we must have in the near future.

The President. The Act under which this Commission was appointed, and has discharged its duty, was supported, I think, by nearly every member of the Boston delegation; and I may be allowed a single moment to add a tribute of respect to that delegation. Boston has been well represented, with one exception, perhaps, during the last two year's, in the State legislature; and I am very happy to know that you are now to be addressed by a member of that delegation, who, as I said, supported this Act when it was passed; who did not always vote with me on every occasion, but who never voted against his conscience, never supported any thing dishonest, or unjust, or unfair ; and who will stand up, I have no doubt, to-night, and speak well his mind, as he did on every fit occasion in the State House, for what he deems just and right, and for the good of the people: Mr. Joseph F. PAUL, whom I am very happy to introduce to you. [Applause.]

\section{SPEECH OF MR. JOSEPH F. PAUL.}

Mr. Chatruar and Gevtleues, - I hardly know what reply to make to the remarks of the gentleman who has just taken his seat. In fact, I think I had better let them go, and allow you to judge for yourselves after I have said what I propose to say. I may say, in the first place, that this is my first appearance upon this stand as a speaker; and, when called upon to speak after such gentlemen as you have listened to to-night, I trust you will make all due allowance for any mistakes that I may make. But I claim the right as a citizen 
of Boston, as a tax-payer of Boston, to express my opinion upon this subject, as upon all others in which I take an interest. The necessity of parks has been made apparent to every gentleman here by those who are better qualified than I am to do so. I believe that there is no man here who does not believe that we are to have parks. I have not heard from such; and I do not believe that there is such a man, unless it is one who does not expect to enjoy them himself, and is unwilling that posterity should.

Taking it for granted that that question is settled, the only question which seems to be before the people is, whether this is the proper time; and I propose to address myself to the consideration of that question. I propose to speak of it as of a private enterprise, and as an individual business-man. It has been explained to you in regard to the condition of the labor-market, and I think that I may say fairly and squarely that labor of the character to be used about parks has not been so cheap for twenty years. Money is cheap; labor is required; parks are wanted; and it is better to keep the men at work, and retain them in the city, than to sustain them and their families at the public cost. It is not like sending out of the country to import something for which we must pay our money. All the money is to be paid to our own citizens; and, unless some show of enterprise is made, we shall lose business-men from this city. They will not stay here, and do nothing, unless the city government makes some show of enterprise. I have had some experience myself in the city government, having been a member of it, whether that is an honor or not; though I hold that the honor or dishonor of any society depends upon one's own conduct. There is always some doubt about making a move in the city government; and, in a matter like the park question, such a meeting as this will be a great encouragement to action. The public feeling on this question is so great, that the parks must be established. The project has been fought no harder than the Water Board was; and where would the city of Boston be, if the friends of that enterprise had not succeeded? Act here to-night, and then let the city goverument do its part. Objections may be made by some gentlemen, made conscientiously; but, five years from 
now, these gentlemen will not remember that they raised any objection.

This meeting is called for the purpose of giving the city government to understand that the business-men, the workingmen, of the city, mean what they say, when they say that they want public parks; and there is no question that an impulse will be given to the action of the city government by this meeting. We are the city of Boston; and the members of the city government act for us.

Gentlemen, it is getting late, and there are those to follow who will entertain you better than I can. But I propose to close with a little story which I heard; and it was in church that I heard it, in an excellent sermon. Just after the war of 1812, our laboring men stood, as they stand to-day, idling about the wharves and public places. That was the case in a little town to the east of Boston. They had enterprising men, as we have now ; and one day a gentleman stepped into a bank, and said to the president, "Mr. President, I am going to build a ship." - "What do you know about shipbuilding?" asked the president. "Nothing. But I can do the business; and there are men here who can do the work. We have the money, and there are the men. I will build the ship, and sell it; you will get your money back; and the profit will be divided among the men.". The idea was a novel one ; but the president wanted to set the wheels of business in motion; and so he said that he would give an answer the next day. The gentleman called promptly the next morning; and the president informed him that the directors had agreed to advance the money. The gentleman then went out among the idle men, and said, "I am going to build a ship, and I want you to do the work. I will pay you enough to live on; and, when the ship is built, we will divide the profit." So they went to work as co-partners, and built the ship, this gentleman generously attending to the business. The ship was built and launched and sold, the money was paid to the bank, and the profits divided. That was the first ship built on the Merrimack in Newburyport, which has since become one of the largest shipbuilding places in Massachusetts. 
So we want something to set the wheels in motion. The eity of Boston can borrow the money, and buy the land, for these parks, more cheaply now than ever again; and the men are ready to do the work. I know of nothing more that I can say. I am glad to see this hall filled to-night. There are men here tonight who have at heart the interests and prosperity of the city of Boston. That is what we are acting for; and I trust that that hundred men will go up to City Hall, and, if the city government will move in the matter, every true man will deem it his duty to stand behind and encourage them.

The President. My friends, the best things and the most enthusiastic meetings must come to an end; but those who wait till the last generally get the best. I have now the pleasure of introducing to you the closing speaker, the Hon. P. A. Collixs.

\section{SPEECH OF THE HON. P. A. COLLINS.}

I know that no word of mine can add to the force of this movement. I am neither great tax-payer nor eminent sanitarist. I cannot hope to equal others who have discussed the moral, æsthetic, sanitary, and economic phases of the question before us. But, happily, there is no need of such discussion now. The question of public parks has been submitted, in all its forms and probable effects, to the ablest, keenest, wisest, of our citizens ; and there is but one answer. The answer is, that we need more out-door life than our sedentary race enjoys, and that public grounds, accessible to all, are not only desirable, but necessary to the moral and physical health of our crowded population.

This is the verdict; and, granted this, there remain but two questions, - "Is this the time?" "Can we afford it?" To some, the present is never the time for any thing. Their motto seems to be, "Don't do to-day what you can put off till tomorrow, because you may not live till to-morrow, and then you won't have to do it at all.". This principle has been acted upon by short-sighted Boston too long; and the result is a melan- 
choly looking-back to the time when improvements could have been made for a tenth or a fifteenth of the present cost. WV are told of our beautiful suburbs, as if they can be suburbs forever. Even now, they are but for the rich. Beware of trespassing in the fields and woods: they are private property. The roads seem to belong to blood-horses and their owners. If you wish to know the future, look at the past. Look back, you aged men, to the fields and gardens of Tremont and Boylston Streets. Look back, you younger men, to rambles through South Boston farms, and land at "South End" sold by the acre. Always comes the old conservative admonition, "Wait!" - yes, wait till the great sea-wall makes City Point of Castle Island, - wait till the now extended arms of Boston clasp Brookline to the bosom of the metropolis, - wait till private avarice and easy legislation, acting intermittently, deface the shore and basin of Charles River, - wait till the dense and ever growing population, bursting from its narrow bounds, spreads itself in streets laid out at random, over what you are pleased to call our suburbs, - wait, in short, till the inevitable happens, and where are your public parks? You may have them, even then, I grant you; but you will have them where the people cannot reach them, and where the cost will be too great. Remember that our city growth is like the growth of all cities in the New World and the Old; and, if we want green places in the future Boston, we must seize them now.

Can we afford the expense? Rather, let us ask, Can Boston afford to be less comfortable to live in, less attractive, less healthy, than sister cities? We can afford police, paved streets, light, sewers, scavengers, a fire department, a board of health, and a score of other agencies, not because they give salaries and employment to certain men, but because the public health and safety require it; we can afford schools, maintained at enormous cost, though it may be conceded that we could live without education; we can afford pure water in abundance, be the expense never so great, because we need it: and, if we need pure air, we can afford to pay for it, to seize the means of having it, and keeping it forever.

And suffer me, with due modesty, to say, that we in this 
meeting - representing as we do the commerce, industries, and professions of this goodly town - have a right to demand that what we ask shall be given us, and that Boston shall take and hold for the use of its people this needed reservation, while yet there is time. I trust our city fathers will need no further admonition than this meeting gives; but, if they should, we are enlisted for the war.

As Cromwell, grimly looking down on the fair fields and shining streams of the land he came to conquer, said, "This is a land worth fighting for," so let us, as we survey the magnificent area of shore and hill and glade which fortune now permits us to dedicate to public use, exclaim, "This, indeed, is worth our effort;" and let us strive for it till the battle is won.

The President. I have been requested to state that the well-known physician, Dr. Edward H. Clarke, who is too ill to be present here to-night, has written a long and interesting letter on the subject of this meeting, which will be published in the morning papers; and I desire that every citizen present will make a point of reading that letter.

\section{LETTER OF DR. EDWARD H. CLARKE.}

Hanmlton A. Hill, Esq., Secretary, \&c.

Dear Sir, - I have the honor to acknowledge the receipt of your note of the $2 d$ inst., requesting me, in the name of the committee who have called a public meeting on the park question, to address to them a letter which shall contain my views upon "the necessity existing at the present time for action on this subject, and upon the Report of the Park Commissioners."

If my views are of any value to the community on this question, or if I could exert any influence, however little, in bringing about a result so necessary to the comfort, prosperity, and health of all the citizens of Boston, as the establishment of a public park within the limits of the city, I should esteem it not less a privilege than a duty to present those views, and exert that influence. 
Among the many and weighty considerations that might be appropriately urged in favor of the establishment of a park in this city, three stand out so prominently, that their importance can scarcely be overestimated. These are, first, the sanitary, second, the educational, and, third, the economic aspects of the question. Let me call your attention briefly to these three points.

The first is the sanitary aspect of the park. The discussion of sewerage and drainage, and of the ventilation of seivers, drains, and houses, with which our community have latterly been made familiar, has impressed upon our citizens, to some extent, the importance of introducing pure air into our houses, and of keeping foul air out of them. The importance of such ventilation cannot be overstated. But we are in danger of forgetting that the importance of ventilating a city is as great as that of ventilating all the houses in it, with this difference, that if a city is not well ventilated, so as to bring fresh air into it, and to keep foul air and poisonous gases out of it, the ventilation of individual dwellings will be of little avail.

The foul air of the streets will not only envelop those who pass through them, but will penetrate the houses that line them, visiting alike the sick and the well, increasing the danger of disease to the former, and diminishing the health and strength of the latter. In proportion as a city increases in size, large open spaces should be reserved. Parks are the lungs of the city. They are more than this : they are reservoirs of oxygen and fresh air. They produce atmospheric currents, which sweep through and purify the streets. Parks not only offer oxygen to all who visit them, but distribute a large amount of this prime necessity of life every where in their neighborhood. Without open spaces appropriately placed, it is impossible, in a large city, to have well ventilated streets, and to keep the air of the houses sweet and clean. Let us remember, moreover, that bad ventilation means poisoned air, and that poisoned air is sure to be followed by a ghastly train of diseases, with an occasional pestilence to remind the inhabitants what a terrible thing it is to disregard sanitary laws.

Improved ventilation is by no means the only sanitary good 
that parks yield to a city wise enough to possess them. A fraction, and only a small fraction, of our population, are able to leave the city cluring the hot months of the year, for the country. When these favored ones reach Nahant, Swampscott, or Newport, or some modest farmhouse, or comfortalle dwelling by the side of the many railroads that lead from the foulness of the city to the purity of the country, or of the mountains, how gladly and enthusiastically they speak of their escape from heat, discomfort, and disease, to coolness, comfort, and health ! But the mass of the community, - the artisans and work-people, whose necessities compel them to remain within the limits of the city, - their families, children, sick ones and all, have at present no such escape from close and impure air.

The carrying of little children who are pinched by cholerainfantum, or spotted by scarlet-fever, or of those who are paralyzed by diphtheria, or distorted by scrofula, or emaciated by consumption, for a few hours a day into the pure air and bright sunlight of an open square, has saved many a life. Many a needless death has occurred, because the city afforded no such opportunity for escape. A few hours' exposure of a child on a mother's lap, or in a basket or carriage, to the freshness of a park, will produce a sleep that never follows opium, chloral, or ether, and will yield a chance for health that no drug can give. For the last few years, Philadelphia has shown a diminished death-rate. Dr. William PEPPER, who has lately investigated the sanitary condition of that city, commenting upon the gratifying fact just stated, says, "While thus showing an average rate of mortality more favorable than that found in any other city containing over 500,000 inhabitants, Philadelphia has recently (1874) attained a degree of healthfulness almost unparalleled; namely, with a population at that time of 775,000 , the number of deaths was but 14,966, giving a death-rate of only 19.3 per thousand. These very favorable results are largely due $t_{0}$ the abundant and cheap water-supply, and to the opportunities given, even to the poorest citizens, for the enjoyment of pure country air in the great Fairmount Park, which contains 2,991 acres. The extent to which this is valued by the citizens may be inferred from the fact, that, during the year 1875 , the 
park was visited by over eleven million persons." There is no reason why a park in Boston should not yield as goor a sanitary result as one in Philadelphia.

While looking at the sanitary aspects of this suljject, let us not forget that a park laid out in accordance with the plan of the Park Commissioners will utilize localities that would otherwise become plague-spots, and nurseries of disease. The low lands along the banks of Charles River, portions of the Back Bay, and other sections that might be mentioned, are sure to become unhealthy localities, - stations for distributing the germs of disease throughout their neighborhood and at a distance from them, - unless they are reserved, and left unoccupied. The most extravagant way of disposing of such localities is for the city to permit them to be built over, "improved" is the phrase, I believe, and then suffer the consequences, in the way of increase of disease and taxes, which follow such sort of improvements.

Let us now pass from the sanitary to the educational aspect of our subject. The educational value of a park to the community of a large city is second only to its sanitary ralue. We are too apt to think that education is the exclusive function of the school, and that books and school-teachers are the only educators. This is a grievous mistake. The education of the home and street, of the workshop and store, of the church and theatre, of the base-ball club and the evening party, of the rumshop and dance-hall, and of the numerous other influences of a great city, is more potent than that of the school. The evil of all evil agencies is intensified, and the good of the good ones diminished, by uncleanness and impure air. Clean hands and a pure heart go together. Foul air prompts to vice, and oxygen to virtue, as surely as sunlight paints the flowers, and ripens the fruits, of our gardens. The tired workman, who, after a day's labor, needs the repose and relaxation of home, is apt to be driven from it by the close atmosphere of the street and house in which he lives. He would, if he could, get into the fresh air of the country ; but, as he cannot do this, he seeks the relief which drink or other excitement yields. If there were a park accessible to him, he with his family would seek it as instinctively as a plant stretches towards the light. The varied op- 
portunities of a park would educate him and his family into the enjoyment of innocent amusements and open-air pleasures. Deprived of these, he and his are educated into the ways of disease and vice by the character of their surroundings. Who that has watched the groups of families, neighbors, and friends, that bivouac by hundreds and thousands on the parks which cluster around, adorn, and invigorate the great cities of Europe, can have failed to notice the innocent amusements and enjoyment of these crowds of young and old, or to be impressed with the fact that the influence of the natural scenes around them, of the trees and plants and flowers, of the pure air and bright skies, is a humanizing and elevating one? It is difficult to compute the value of such an influence in dollars and cents, or to measure it by any scale that the market acknowledges; but it is, nevertheless, a real, substantial, and potent one. If our large cities are the pride and boast of the republic, they also contain the greatest elements of danger to the state and the nation. Ignorance and vice, disease and crime, crowd themselves into cities. There they find their best hiding-places, their surest protection, and their most defenceless victims. It makes one tremble to think of the thousands of youth in our cities whom the school and the church do not reach, and who are moulded by these influences into the worst and lowest forms of humanity. They can not and will not go out into the country themselves, except upon some errand of violence and crime. The city should therefore bring the country to them, and give them a chance, at least, to experience its humanizing and blessed influence.

A park, or a series of parks, with its trees and running waters, its grass and plants and flowers, its variegated surface and changing views, and all the beauty with which such scenes are flooded, supplements the labor of the church and school in educating, refining, and elevating the community. There will be less gambling, drinking, and quarrelling in Boston, when the mass of its inhabitants shall be allowed to partake of the blessing and beauty of a public park.

These considerations naturally bring us to the third point which has been mentioned, viz., the economic aspect of the 
matter. Few will deny the truth of the above statements; but the admission of their truth is apt to be coupled with the reply, "The park will cost so much, we cannot afford it." It is true that it will cost a good deal, but not so much to each household as the inevitable cost of the sickness, vice, and death, which the opportunities that a park provides would prevent. Are human life and health and virtue so cheap, that we can afford to count the cost of procuring and maintaining them? Are vice, crime, and disease so unimportant, that we can afford to let them thrive, and propagate themselves indefinitely? We cannot repeat too often, or ponder too seriously, the statement made in the first report of the Park Commissioners: "Nothing is so costly as sickness and disease: nothing so cheap as health. Whatever promotes the former is the worst sort of extravagance: whatever fosters the latter is the truest economy." The truth is, it will cost the city of Boston more to get on without a park than to incur the expense of buying and taking care of one. We pay at present an enormous sum yearly for the maintenance of hospitals, prisons, jails, and workhouses. It is not asserted that the establishment of a park will depopulate these institutions, or render them unnecessary ; but no sanitarian will deny that one result, and a most important one, of the establishment of a park, would be to diminish the number of those who are compelled to resort to these institutions. A greater economy than all this would be found to accrue to each household in the increased comfort, diminished sickness, more vigorous health, and ample enjoyment, that would be added to all its members.

Boston has been long and justly celebrated for its health, beauty, and wealth." If it loses the two first of these distinctions, how long will it retain the last? Business and population will turn away from an unhealthy and unattractive town. Defective sewerage and imperfect drainage are sapping the health; and the occupation of the suburbs by houses, manufactories, workshops, and stores, is destroying the beauty of the city. Will the merchants of Boston, whose reputation for intelligence, sagacity, and enterprise has gone out to the ends of the world, permit a false economy to blind them to the importance of this whole matter? 
Of the details of the financial question, I am not qualified to speak; but I will venture a single remark. It seems only a piece of common sense to one unfamiliar with the intricate problems of finance to say, that, if the present time is one of great depression of values, it is precisely the time when a wealthy corporation like the city of Boston can purchase the land for a park at the lowest price, and therefore should do it.

Permit me to add a single word with regard to the plan proposed by the Commissioners. It offers more advantages, and fewer disadvantages, than any other that has been proposed. This might be expected, when we reflect that it was prepared in accordance with the advice of Mr. OlmsteAd, than whom no one is better qualified to advise in such matters. It may be safely asserted, that if Boston should accept this plan, and authorize it to be carried out, the city would possess a park unique in its character, of unrivalled beauty, and one which all our citizens, young and old, rich and poor, would greatly enjoy, and of which, if they once obtained it, they would never be bribed to dispossess themselves.

The Rev. Dr. Ellis, in his recent eloquent address at the centennial anniversary of the evacuation of Boston, used the following language, "As I read the history of our fathers in all their generations, their toil and virtue seem to me to have been the noblest, in their steady regard for the welfare and happiness of their posterity. And as I firmly believe that no single individual can follow the highest pattern of an earthly life, unless his hope and faith link on to a future, so I find it proved in all biographies and annals, that all unselfish, noble, and heroic lives are those which parents lead for their children and their children's children. We have such lives among us in city, state, and nation, private and public, high and humble." May we be true to the reputation and tradition of our fathers, and provide as intelligently for the well-being of ourselves and our posterity as they provided for themselves and for us!

I am, with great respect, very truly yours,

Edw. H. Clarke.

Arlifgtox Street, Bostox, June 6, 1876. 
The President, in calling for a rote on the resolutions, said, I merely wish to say that old Faneuil Hall can stand a great deal of noise ; but still I would recommend, for the benefit of future audiences, that you should not take off the roof, nor burst the windows, nor put out the gas. [Laughter.]

The resolutions were unanimously agreed to; and the following committee of a hundred, to present the result of the meeting to the city government, was appointed; the assembly dispersing shortly after ten o'clock.

\section{COMMITTEE OF ONE HUNDRED.}

Joseph S. Ropes

Marshall P. Wilder

Oliver W. Holmes, M.D.

Richard Frothingham

Samuel Cabot, M D.

J. Baxter Upham, M.D.

Thomas J. Gargan

George C. Richardson

John P. Reynolds, M.D.

John W. Candler

George B. Chase

William E. Coffin

- Francis A. Osborn

Ralph Crooker

Pobert Seaver

J. Mitchell Galvin

WV. IV. Morland, M.D.

Richard Olney

Joseph W. Balch

C. Allen Richards

Charles L. Thayer

William E. Perkins

James Edwards

J. Tisdale Bradlee

Jonas Fitch

James Sturgis

J. N. Borland, M.D.

Charles IV. Slack

Clement H. Hill

William V. Hutchings

William T. Hart
William P. Hunt

Hamilton A. Hill

Joseph F. Paul

Charles W. Wilder

M. F. Dickinson, jun.

P. A. Collins

Albert Bowker

John C. Pratt

Jerome Jones

H. H. A. Beach, M.D.

S. J. Langmaid, M.D.

Joseph H. Chadwick

Benjamin Deane

J. J. M.Nutt

Nath: Adams

B. F. Nourse

Martin Griffin

John J. May

M. Duherty

Thomas B. Curtis, M.D.

Thomas Gogin

Royal E. Robbins

William W. Clapp

E. B. Haskell

C. F. Donnelly

T. Quincy Browne

F. E. Goodrich

Charles IV. Morris

D. N. Skillings

Hales W. Suter

Henry Smith 
Robert Johnson

Asa P. Potter

William J. R. Evans

Cliarles Nowell

Jacob Pfaff

Eben D. Jordan

George Woods Rice

Thomas Mack

Lewis Coleman

Charles F. Choate

Roland Worthington

M. B. Leonard, M.D.

A. H. Lewis

George G. Crocker

Charles L. Haley

Waldo Adams

John F. Payson

Hollis Hunnewell

Martin Hayes
William Atherton

Charles J. Bishop

Aaron D. Williams

Henry C. Morse

S. Parkman Dexter

George P. King

Albert Thompson

Joseph Dix

H. M. Bearce

Wiliam B. Bacon

George O. Carpenter

Henry J. Nazro

J. Kent Crowley

James N. Spillane

IV. H. Forbes

J. B. Dacey

James F. Gray

John Bigelow

A. Claxton Cary 
105

105 
106 
107 





BOSTON COLLEGE

$39031033 \quad 430158$

\section{WUITMPLE VOLUMES SOUND TOSETHEA}

\section{O'WELLLLBRARY BOTTON COLLEGE}




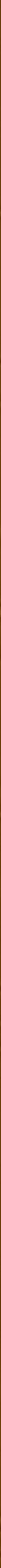

